\title{
Implementasi Digital Receptionist berbasis Web dan Android
}

\author{
Besus Maula Sulthon, Eva Zuraidah* \\ Fakultas Teknologi Informasi, Program Studi Sistem Informasi, Universitas Nusa Mandiri, Jakarta, Indonesia \\ Email: 'besus.bem@nusamandiri.ac.id, 2,"eva.evz@nusamandiri.ac.id \\ Submitted: 08/11/2021; Accepted: 27/11/2021; Published: 30/11/2021
}

\begin{abstract}
Abstrak-Seiring dengan perkembangan Teknologi Informasi yang semakin pesat dan penerapannya yang telah luas ke berbagai aspek atau bidang usaha, teknologi infomasi juga telah banyak dimanfaatkan oleh industry ataupun organisasi lainnya. Pemanfaatannya bertujuan untuk memudahkan pengguna dan memberikan efesiensi pada suatu bidang usaha dalam menjalankan aktivitasnya. Situasi pandemi virus corona menuntut kita secara optimal tidak bersentuhan dengan orang lain atau menjaga jarak. Dari fakta yang ada, banyak perusahaan atau perkantoran masih melaksanakan penerimaan tamu secara manual dengan menggunakan jasa resepsionis yang akan mengakibatkan tamu harus menukar identitasnya untuk mendapatkan akses kantor, serta tingginya sarana dan prasarana teknologi informasi tidak diimbangi dengan kesadaran masyarakat Indonesia untuk menggunakannya secara optimal. Dari permasalahan tersebut, peneliti mengajukan penelitian sebagai solusi alternatif berupa rancangan bangun sistem aplikasi web dan Android untuk menggantikan fungsi reseptionis atau yang dinamakan Digital Receptionist menggunakan pendekatan berbasis Terstruktur, Design Method, PHP dan MYSQL dengan pengembangan aplikasi berbasis web dan android. Hasil yang dicapai diharapkan mampu menghindari sentuhan tangan atau menjaga jarak dan meningkatkan efisiensi dan efektivitas proses penerimaan tamu. Simpulan yang didapat adalah dengan adanya sistem Digital Receptionist ini, selain dapat meningkatkan efesiensi dan efektivitas proses penerimaan tamu dan menghindari sentuhan tangan atau jaga jarak
\end{abstract}

Kata Kunci: Digital Receptionist; Web; Android

Abstract-Along with the rapid development of Information Technology and its wide application to various aspects or fields of business, information technology has also been widely used by industry or other organizations. Its utilization aims to facilitate users and provide efficiency in a business field in carrying out its activities. The situation of the coronavirus pandemic demands that we optimally not come into contact with other people or keep our distance. From the facts, many companies or offices still carry out manual receptions using receptionist services which will result in guests having to change their identities to get office access, and the high level of information technology facilities and infrastructure is not matched by the awareness of the Indonesian people to use them optimally. From these problems, the researcher proposes research as an alternative solution in the form of designing web and Android application systems to replace the receptionist function or what is called Digital Receptionist using a structured approach, Design Method, PHP, and MYSQL with web and android based application development. The results achieved are expected to be able to avoid touching hands or keep a distance and increase the efficiency and effectiveness of the guest reception process. The conclusion obtained is that with this Digital Receptionist system, besides being able to increase the efficiency and effectiveness of the guest reception process and avoid touching hands or keeping a distance.

Keywords: Digital Receptionist; Web; Android

\section{PENDAHULUAN}

COVID-19 merupakan penyakit menular yang disebabkan oleh sindrom pernapasan akut coronavirus 2 (severe acute respiratory syndrome coronavirus 2 atau SARS-CoV-2)[1].

Pemerintah menerapkan Pembatasan Sosial Berskala Besar Transisi (PSBB Transisi) atau New Normal demi memutus mata rantai penyebaran virus corona dan memulihkan perekonomian negara. Tentu saja hal ini harus didasari oleh kesadaran masyarakat untuk tidak berkumpul, menjaga jarak, hindari berjabat tangan, menjaga kebersihan, sering mencuci tangan, dan tetap mematuhi protokol yang ada ketika berada diluar rumah[2].

Di era New Normal ini, kita dituntut untuk kembali menjalankan aktivitas dengan ubah kebiasaan baru dan menjalankan protocol kesehatan. Di perkantoran sering terkendala pada fungsi resepsionis saat menerima tamu. Untuk mendapat akses masuk kedalam gedung. Tamu harus menyerahkan kartu identitas diri sebagai alat tukar untuk akses ke dalam gedung. Sehingga akan terjadi nya tatap muka antara resepsionis dengan tamu dan bersentuhan kartu identitas milik tamu maupun kartu akses kantor. Yang menyebabkan bisa terjadinya penuluran virus Covid-19 pada saat pelaksanaan tersebut.

Artificial intelligence merupakan suatu kecerdasan buatan yang terintegrasi dengan sistem, secara umum teknisnya sistem Artificial intelligence akan secara otomatis dapat membaca gambar, suara maupun keinginan seseorang mengenai sesuatu. Kecerdasan buatan merupakan ilmu yang mempelajari tentang bagaimana membangun suatu sistem komputer yang meunjukkan kecerdasan dengan berbagai cara. Dengan adanya pemanfaatan Artificial intelligence pada Digital Receptionist diharapkan mampu mengatasi permasalahan saat mendata tamu, memberikan hak akses tamu tanpa bersentuhan tangan, lebih efesien dan efektif dalam pelaksanaannya [3].

Metode Artificial Inteligence sendiri adalah metodologi pengembangan perangkat lunak yang didasarkan pada prinsip-prinsip pengembangan system jangka pendek yang memerlukan adaptasi cepat dari pengembang terhadap perubahan dalam bentuk apapun. Langkah-langkah yang digunakan dalam metode agile yaitu perencanaan, implementasi, pengujian (test), dokumentasi, deployment dan pemeliharaan [6]. 
Metode Artificial Inteligence memiliki keefektifan lebih baik dari pada model tradisional yang kurang baik dan kurang efisien, tetapi metode ini juga bukan metode yang prosesnya bersifat menentu yang berarti prosesnya tidak mendetail dalam membuat tipe model yang telah diberikan, walaupun terdapat cara dalam membuatnya menjadi modeler yang efektif[7].

\section{METODOLOGI PENELITIAN}

\subsection{Tahapan Pengembangan Aplikasi}

Metode agile sendiri adalah metodologi pengembangan perangkat lunak yang didasarkan pada prinsip-prinsip pengembangan system jangka pendek yang memerlukan adaptasi cepat dari pengembang terhadap perubahan dalam bentuk apapun. Langkah-langkah yang digunakan dalam metode agile yaitu perencanaan, implementasi, pengujian (test), dokumentasi, deployment dan pemeliharaan [6].

Agile memiliki keefektifan lebih baik dari pada model tradisional yang kurang baik dan kurang efisien, tetapi metode ini juga bukan metode yang prosesnya bersifat menentu yang berarti prosesnya tidak mendetail dalam membuat tipe model yang telah diberikan, walaupun terdapat cara dalam membuatnya menjadi modeler yang efektif [7].

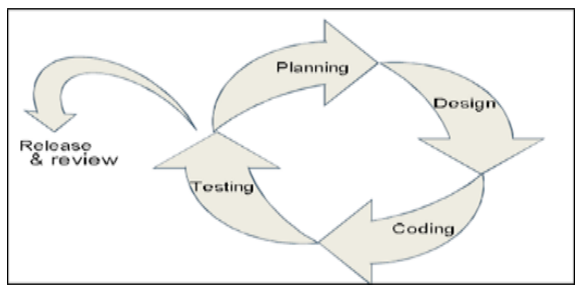

Gambar 1. Metode Agile Development

Berikut akan dijelaskan tahapan-tahapan dalam metode (agile) [6]:

1. Perancangan Sistem

Perencanaan sistem merupakan suatu tahapan awal dalam pembuatan sistem yang memerlukan suatu proses. Adapun tahapan-tahapan dalam perencanaan sistem cloud hosting yaitu tahap analisis sistem dan spesifikasi kebutuhan sistem. Dalam tahap analisis system ini akan dirancang suatu layanan cloud yang dapat disesuaikan dengan kebutuhan dan permintaan perusahaan yaitu layanan cloud hosting dengan layanan database cloud menggunakan Cloud SQL Database.

2. Implementasi

Setelah dilakukan analisis sistem dan penentuan kebutuhan perangkat maka langkah selanjutnya adalah pengimplementasian deploying dan provisioning sistem yaitu persiapan menu untuk perusahaan, penginstallan dan konfigurasi terhadap perangkat keras dan perangkat lunak yang dibutuhkan untuk dapat meletakkan Cloud SQL Database perusahaan ke pusat data.

3. Pengujian

Sebuah Sistem hosting dapat dikatakan sebagai sebuah sistem cloud hosting ketika prasyarat layanan cloud computing dapat terpenuhi. Layanan cloud computing yang merupakan prasyarat utama dari sebuah sistem cloud computing meliputi Broad Network Access, Resource Pooling, Measured Services, Rapid Elasticity, Self Service..

4. Tahap Deployment

Proses deployment dilakukan dengan cara menyebarkan informasi mengenai layanan baru kepada para perusahaan yang sebelumnya telah menggunakan server konvensional. Selain itu proses deployment juga dilakukan dengan cara publikasi melalui website resmi dari penyedia layanan cloud provider.

5. Tahap Pemeliharaan

Tahap pemeliharaan bertujuan untuk menjaga peralatan dan sistem dalam kondisi terbaik. Ketika dijalankan mungkin saja masih ada kesalahan kecil yang tidak ditemukan sebelumnya, atau ada penambahan fitur-fitur serta add on yang belum ada pada software tersebut

\subsection{Entity Relationship Diagram (ERD)}

ERD adalah bentuk paling awal dalam melakukan perancangan basis data relasional. Jika menggunakan OODMBS maka perancangan ERD tidak perlu dilakukan

Simbol-simbol dalam ERD (Entity Relationship Diagram) adalah sebagai berikut[8] [9] :

1. Entitas: suatu yang nyata atau abstrak yang mempunyai karakteristik dimana kita akan menyimpan data.

2. Atribut: ciri umum semua atau sebagian besar instansi pada entitas tertentu.

3. Relasi: hubungan alamiah yang terjadi antara satu atau lebih entitas.

4. Link: garis penghubung atribut dengan kumpulan entitas dan kumpulan entitas dengan relasi. 
Journal of Computer System and Informatics (JoSYC)

Volume 3, No. 1, November 2021, Page 57-64

ISSN 2714-8912 (media online)

ISSN 2714-7150 (media cetak)

DOI 10.47065/josyc.v3i1.947

\section{HASIL DAN PEMBAHASAN}

\subsection{Rancangan Unified Modeling Language (UML)}

Pada bagian ini di jelaskan rancangan dari aplikasi yang di buat dengan menggunakan UML

A. Use Case Diagram

1. Use Case Diagram Halaman Tamu

Berikut merupakan use case diagram untuk halaman tamu.

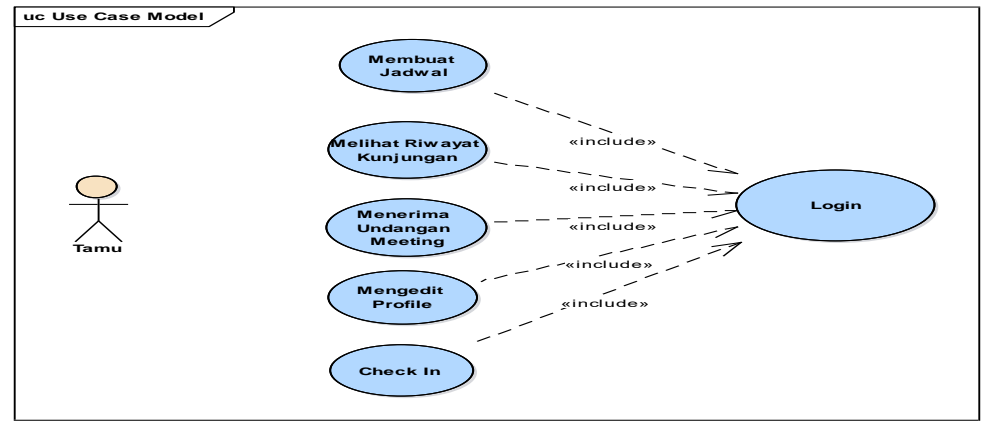

Gambar 2. Use case diagram halaman tamu

2. Use Case Diagram Halaman Karyawan

Berikut merupakan use case diagram untuk halaman karyawan.

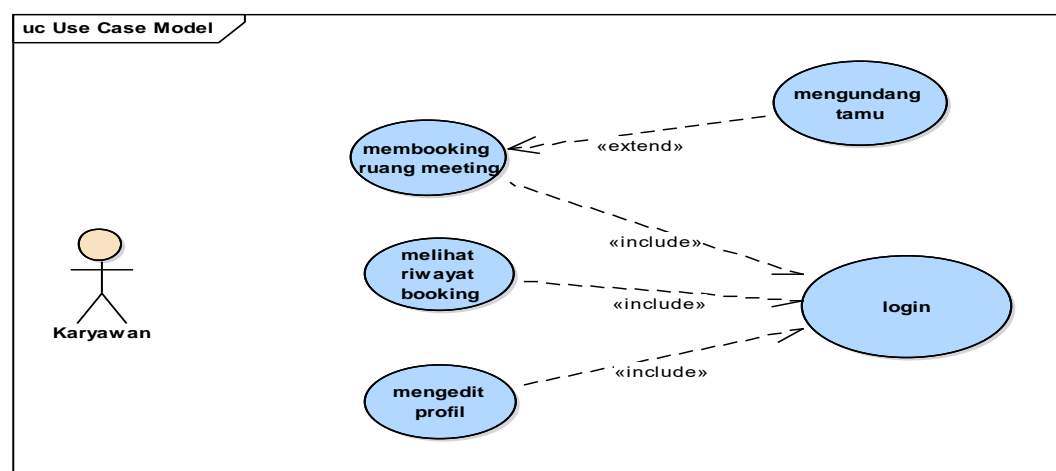

Gambar 3. Use case diagram halaman karyawan

\section{B. Activity Diagram}

Activity Diagram Modul Tamu membuat jadwal kunjungan

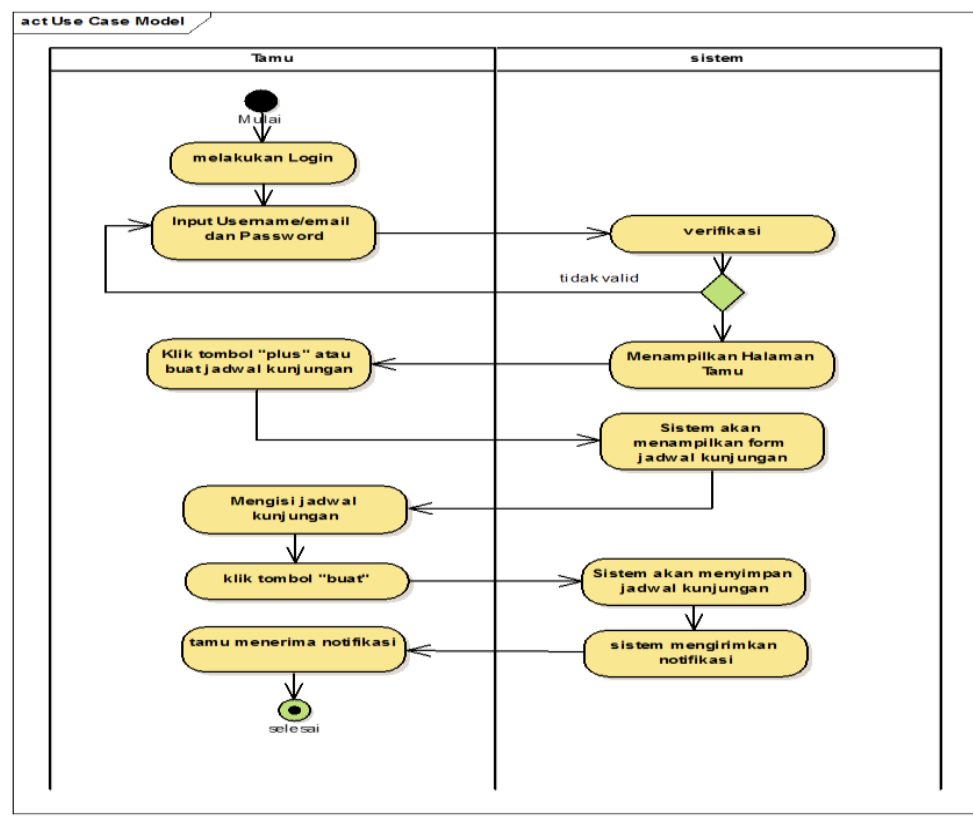

Gambar 4. Aktiviti diagram 
Journal of Computer System and Informatics (JoSYC)

Volume 3, No. 1, November 2021, Page 57-64

ISSN 2714-8912 (media online)

ISSN 2714-7150 (media cetak)

DOI 10.47065/josyc.v3i1.947

Penjelasan:

1. Tamu melakukan login, dengan memasukan username / email dan password

2. Bila username dan passwordnya maka sistem mempverifikasi dan menampilkan halaman tamu.

3. Tamu membuat jadwal kunjungan, kemudian sistem menampilkan form kunjungan

4. Tamu mengisi jadwal kunjungan dan buat, kemuidan sistem menyimpan jadeal kunjungan, kemudian sistem mengirimkan notifikasi kepada tamu.

\section{Class Diagram}

Dalam rancangan system diginal resepsionis ini terdapat 12 class diagram, yang masing-masingnya mewakili dari object permsalahan yang akan di selesaikan, yang terdiri dari class jabatan, class tamu, class vendor, class admin, class transaksi, class resepsionis, class ucapan, class digital resepsionis, class booking_hd ( selesai ) serta class booking_at ( mulai ) yang kesemuanya class saling berintegrasi sesuai dengan kebutuhannya.

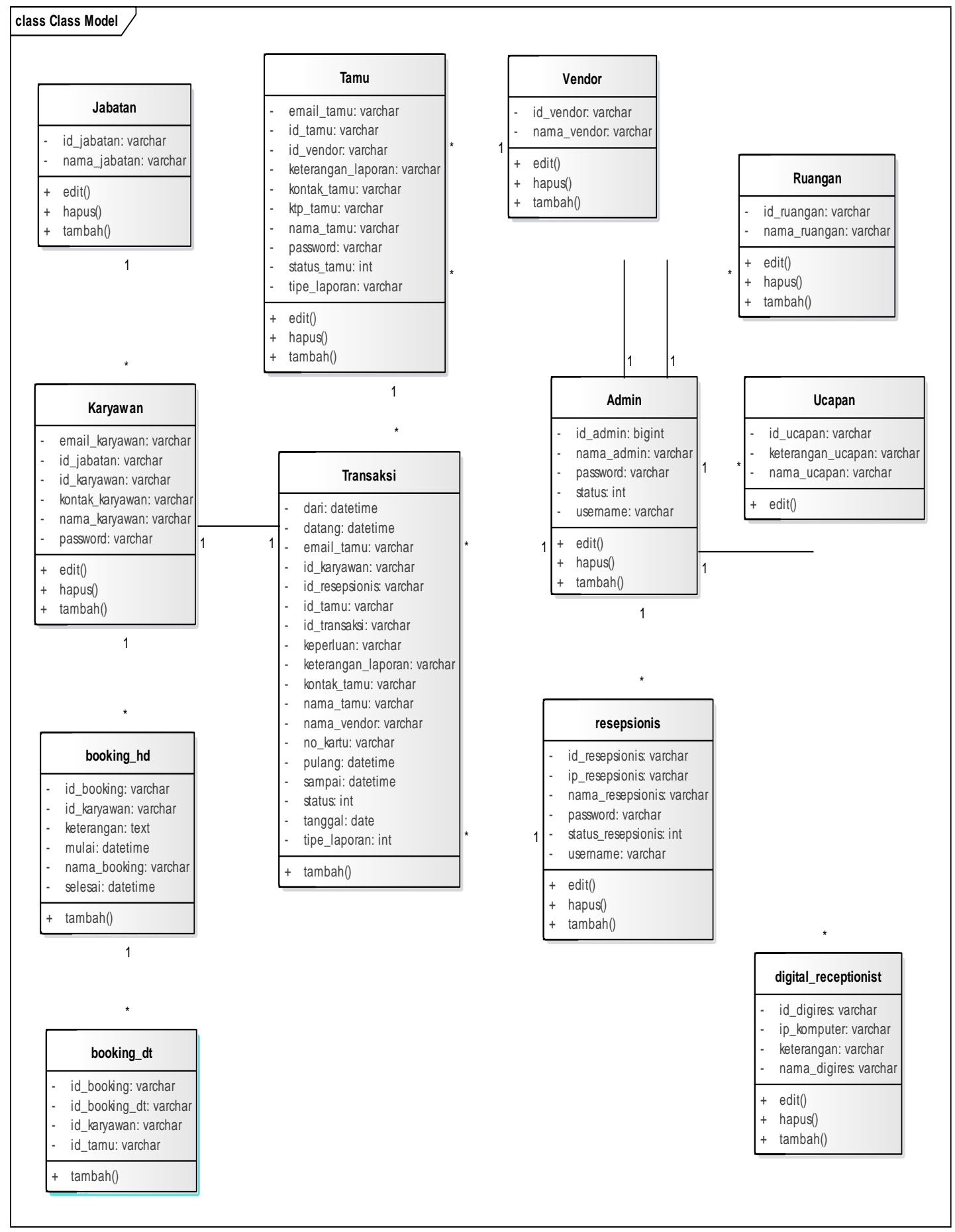

Gambar 5. Class diagram 
Journal of Computer System and Informatics (JoSYC)

Volume 3, No. 1, November 2021, Page 57-64

ISSN 2714-8912 (media online)

ISSN 2714-7150 (media cetak)

DOI 10.47065/josyc.v3i1.947

\subsection{Implementasi Program}

\section{Halaman login}

Halaman Login untuk Admin dimana harus memasukan dulu username dan pasword, dengan cara klik login, baru Admin bisa masuk kehalaman berikutnya.

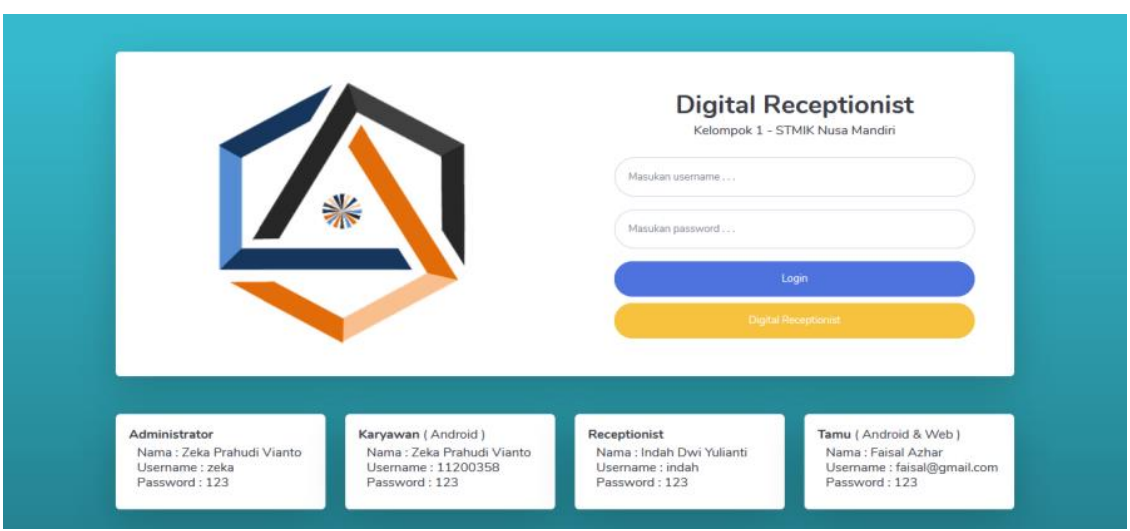

Gambar 6. Halaman Login Modul Admin

\section{Halaman Utama}

Halaman Utama ini didalamnya ada beberapa file untuk bisa masu kedalam halaman berikutnya di dashboord ini.

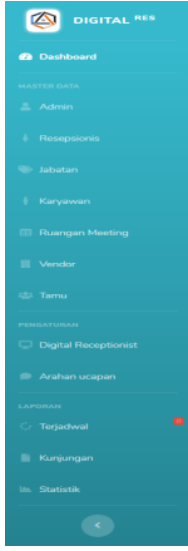

\section{Halaman Admin}

Halaman Admin ini untuk admin menambah dan mengisi data dari Admin itu sendiri.
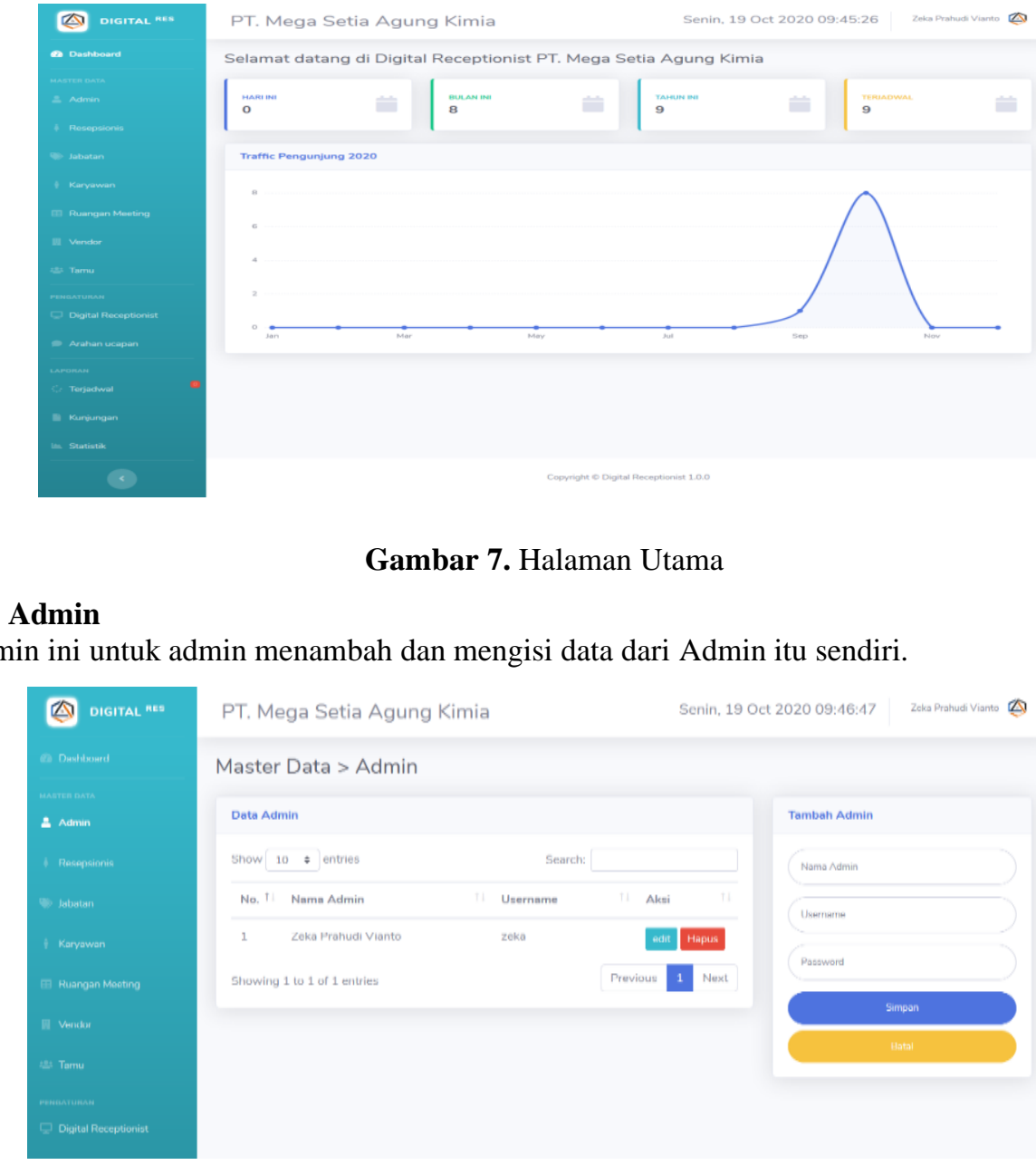

Gambar 7. Halaman Utama

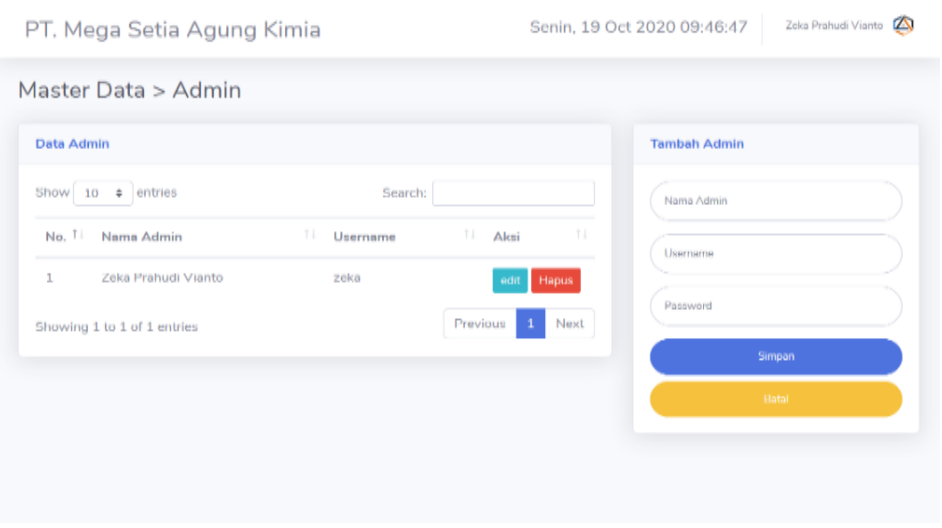

Gambar 8. Halaman Admin

\subsection{Pengujian Aplikasi}

Dari tabel black box testing ini gunanya untuk menguji apakah aplikasi yang dibuat sudah selesuai yang di inginkan dan sudah tidak mempunyai kesalan yang beresiko tinggi , maka harus dibuat tabe lpengujian tersebut. 
Journal of Computer System and Informatics (JoSYC)

Volume 3, No. 1, November 2021, Page 57-64

ISSN 2714-8912 (media online)

ISSN 2714-7150 (media cetak)

DOI 10.47065/josyc.v3i1.947

\section{Black Box Form Login}

Pada Tabel Black Testing login ini digunakan untuk mengetahui apakah login sudah sesuai yang di masukan, bila tidak sesuai maka akan tidak benar, jika sesuai maka benar.

Tabel 1. Black Box Testing Form Login

\begin{tabular}{|c|c|c|c|c|c|}
\hline No & Skenario Penujian & Test Case & $\begin{array}{l}\text { Hasil yang } \\
\text { Diharapkan }\end{array}$ & $\begin{array}{c}\text { Hasil } \\
\text { Pengujian }\end{array}$ & Kesimpulan \\
\hline 1 & $\begin{array}{l}\text { Mengosongkan semua } \\
\text { isian pada login, lalu } \\
\text { langsung mengklik tombol } \\
\text { login }\end{array}$ & $\begin{array}{l}\text { Username : (kosong) } \\
\text { Password : (kosong) }\end{array}$ & $\begin{array}{l}\text { Sistem akan } \\
\text { menolak } \\
\text { akses login dan } \\
\text { menampilkan pesan } \\
\text { "Gagal Login" }\end{array}$ & $\begin{array}{c}\text { Sesuai } \\
\text { Harapan }\end{array}$ & Valid \\
\hline 2 & $\begin{array}{l}\text { Hanya mengisi } \\
\text { data username dan } \\
\text { Mengosongkan } \\
\text { password, lalu } \\
\text { mengklik tombol } \\
\text { login }\end{array}$ & $\begin{array}{l}\text { Username : admin } \\
\text { Password : (kosong) }\end{array}$ & $\begin{array}{l}\text { Sistem akan } \\
\text { menolak } \\
\text { akses login dan } \\
\text { menampilkan pesan } \\
\text { "Gagal Login" }\end{array}$ & $\begin{array}{c}\text { Sesuai } \\
\text { Harapan }\end{array}$ & Valid \\
\hline 3 & $\begin{array}{l}\text { Hanya mengisi } \\
\text { data password dan } \\
\text { mengosongkan } \\
\text { username, lalu } \\
\text { mengklik tombol } \\
\text { login }\end{array}$ & $\begin{array}{l}\text { Username : (kosong) } \\
\text { Password : rahasia }\end{array}$ & $\begin{array}{l}\text { Sistem akan } \\
\text { menolak } \\
\text { akses login dan } \\
\text { menampilkan pesan } \\
\text { "Gagal Login" }\end{array}$ & $\begin{array}{r}\text { Sesuai } \\
\text { Harapan }\end{array}$ & Valid \\
\hline 4 & $\begin{array}{l}\text { Menginput dengan } \\
\text { kondisi salah satu } \\
\text { benar dan satunya } \\
\text { salah, lalu langsung } \\
\text { klik login }\end{array}$ & $\begin{array}{l}\text { Username : admin } \\
\text { (benar) } \\
\text { Password : asal (salah) }\end{array}$ & $\begin{array}{l}\text { Sistem akan } \\
\text { menolak } \\
\text { akses login dan } \\
\text { menampilkan pesan } \\
\text { "Gagal Login" }\end{array}$ & $\begin{array}{r}\text { Sesuai } \\
\text { Harapan }\end{array}$ & Valid \\
\hline 5 & $\begin{array}{l}\text { Menginput data } \\
\text { login yang benar } \\
\text { lalu langsung klik } \\
\text { login }\end{array}$ & $\begin{array}{l}\text { Username : admin } \\
\text { (benar) } \\
\text { Password : rahasia } \\
\text { (benar) }\end{array}$ & $\begin{array}{l}\text { Sistem langsung } \\
\text { menerima login } \\
\text { kemudian } \\
\text { diarahkan ke } \\
\text { halaman utama }\end{array}$ & $\begin{array}{r}\text { Sesuai } \\
\text { Harapan }\end{array}$ & Valid \\
\hline
\end{tabular}

\section{Black Box Testing Buat Jadwal}

Pada Tabel Black Testing buat jadwal ini digunakan untuk mengetahui apakah untuk buat jadwal sudah sesuai yang di masukan,seperti tanggal, bulan tahun, harus benar , bila tidak ada yang kosong maka akan tidak benar, jika sesuai maka benar.

Tabel 2. Black Box Testing Buat Jadwal

\begin{tabular}{|c|c|c|c|c|c|}
\hline No & $\begin{array}{l}\text { Skenario } \\
\text { Penujian } \\
\end{array}$ & Test Case & Hasil yang Diharapkan & $\begin{array}{c}\text { Hasil } \\
\text { Pengujian }\end{array}$ & Kesimpulan \\
\hline 1 & $\begin{array}{l}\text { Mengosongkan } \\
\text { semua isian pada } \\
\text { form buat } \\
\text { jadwal, lalu } \\
\text { langsung } \\
\text { mengklik } \\
\text { tombol buat }\end{array}$ & $\begin{array}{l}\text { Tanggal : (Kosong) } \\
\text { Dari : (Kosong) } \\
\text { Sampai : (Kosong) } \\
\text { PIC : (Kosong) } \\
\text { Keperluan : (Kosong) }\end{array}$ & $\begin{array}{l}\text { Sistem akan menolak buat } \\
\text { jadwal dan menampilkan } \\
\text { pesan "Lengkapi semua data" }\end{array}$ & $\begin{array}{c}\text { Sesuai } \\
\text { Harapan }\end{array}$ & Valid \\
\hline 2 & $\begin{array}{l}\text { Hanya mengisi } \\
\text { data Tanggal } \\
\text { dan data yang } \\
\text { lain di } \\
\text { kosongkan, lalu } \\
\text { klik tombol buat }\end{array}$ & $\begin{array}{l}\text { Tanggal : Tanggal } \\
\text { Kunjungan } \\
\text { Dari : (Kosong) } \\
\text { Sampai : (Kosong) } \\
\text { PIC : (Kosong) } \\
\text { Keperluan : (Kosong) }\end{array}$ & $\begin{array}{l}\text { Sistem akan menolak buat } \\
\text { jadwal dan menampilkan } \\
\text { pesan "Lengkapi semua data" }\end{array}$ & $\begin{array}{c}\text { Sesuai } \\
\text { Harapan }\end{array}$ & Valid \\
\hline 3 & $\begin{array}{l}\text { Hanya mengisi } \\
\text { data Dari dan } \\
\text { data yang lain di }\end{array}$ & $\begin{array}{l}\text { Tanggal : (Kosong) } \\
\text { Dari : jam mulai } \\
\text { pelaksanaan } \\
\text { Sampai : (Kosong) }\end{array}$ & $\begin{array}{l}\text { Sistem akan menolak buat } \\
\text { jadwal dan menampilkan } \\
\text { pesan "Lengkapi semua data" }\end{array}$ & $\begin{array}{c}\text { Sesuai } \\
\text { Harapan }\end{array}$ & Valid \\
\hline
\end{tabular}




\begin{tabular}{|c|c|c|c|c|c|}
\hline No & $\begin{array}{c}\text { Skenario } \\
\text { Penujian } \\
\end{array}$ & Test Case & Hasil yang Diharapkan & $\begin{array}{c}\text { Hasil } \\
\text { Pengujian }\end{array}$ & Kesimpulan \\
\hline & kosongkan, lalu & PIC : (Kosong) & & & \\
\hline 4 & $\begin{array}{l}\text { Hanya mengisi } \\
\text { data Sampai dan } \\
\text { data yang lain di } \\
\text { kosongkan, lalu } \\
\text { klik tombol buat }\end{array}$ & $\begin{array}{l}\text { Keperluan : (Kosong) } \\
\text { Tanggal : (Kosong) } \\
\text { Dari : (Kosong) } \\
\text { Sampai : jam selesai } \\
\text { pelaksanaan } \\
\text { PIC : (Kosong) } \\
\text { Keperluan : (Kosong) }\end{array}$ & $\begin{array}{l}\text { Sistem akan menolak buat } \\
\text { jadwal dan menampilkan } \\
\text { pesan "Lengkapi semua data" }\end{array}$ & $\begin{array}{c}\text { Sesuai } \\
\text { Harapan }\end{array}$ & Valid \\
\hline 5 & $\begin{array}{l}\text { Hanya mengisi } \\
\text { data PIC dan } \\
\text { data yang lain di } \\
\text { kosongkan, lalu } \\
\text { klik tombol buat }\end{array}$ & $\begin{array}{l}\text { Tanggal : (Kosong) } \\
\text { Dari : (Kosong) } \\
\text { Sampai : (Kosong) } \\
\text { PIC : Karyawan yang } \\
\text { bersangkutan } \\
\text { Keperluan : (Kosong) }\end{array}$ & $\begin{array}{l}\text { Sistem akan menolak buat } \\
\text { jadwal dan menampilkan } \\
\text { pesan "Lengkapi semua data" }\end{array}$ & $\begin{array}{c}\text { Sesuai } \\
\text { Harapan }\end{array}$ & Valid \\
\hline 6 & $\begin{array}{l}\text { Hanya mengisi } \\
\text { data Keperluan } \\
\text { dan data yang } \\
\text { lain di } \\
\text { kosongkan, lalu } \\
\text { klik tombol buat }\end{array}$ & $\begin{array}{l}\text { Tanggal : (Kosong) } \\
\text { Dari : (Kosong) } \\
\text { Sampai : (Kosong) } \\
\text { PIC : (Kosong) } \\
\text { Keperluan : Keperluan } \\
\text { kunjungan }\end{array}$ & $\begin{array}{l}\text { Sistem akan menolak buat } \\
\text { jadwal dan menampilkan } \\
\text { pesan "Lengkapi semua data" }\end{array}$ & $\begin{array}{c}\text { Sesuai } \\
\text { Harapan }\end{array}$ & Valid \\
\hline 7 & $\begin{array}{l}\text { Mengisi } \\
\text { Tanggal dengan } \\
\text { kemarin }\end{array}$ & $\begin{array}{l}\text { Tanggal : Tanggal } \\
\text { Kemarin } \\
\text { Dari : : jam mulai } \\
\text { pelaksanaan } \\
\text { Sampai : : jam selesai } \\
\text { pelaksanaan } \\
\text { PIC : Karyawan yang } \\
\text { bersangkutan } \\
\text { Keperluan : Keperluan } \\
\text { kunjungan }\end{array}$ & $\begin{array}{l}\text { Sistem akan menolak buat } \\
\text { jadwal dan menampilkan } \\
\text { pesan "Tanggal tidak boleh } \\
\text { kurang dari hari ini" }\end{array}$ & $\begin{array}{c}\text { Sesuai } \\
\text { Harapan }\end{array}$ & Valid \\
\hline 8 & $\begin{array}{l}\text { Mengisi } \\
\text { seluruh data buat } \\
\text { jadwal dan } \\
\text { tanggal } \\
\text { kunjungan hari } \\
\text { ini, lalu klik } \\
\text { tombol buat }\end{array}$ & $\begin{array}{l}\text { Tanggal : Tanggal } \\
\text { Kunjungan } \\
\text { Dari : : jam mulai } \\
\text { pelaksanaan } \\
\text { Sampai : : jam selesai } \\
\text { pelaksanaan } \\
\text { PIC : Karyawan yang } \\
\text { bersangkutan } \\
\text { Keperluan : Keperluan } \\
\text { kunjungan }\end{array}$ & $\begin{array}{l}\text { Sistem langsung menerima } \\
\text { buat jadwal kemudian data } \\
\text { akan tersimpan }\end{array}$ & $\begin{array}{c}\text { Sesuai } \\
\text { Harapan }\end{array}$ & Valid \\
\hline
\end{tabular}

\section{KESIMPULAN}

Setelah dilakukan pengujian dan mengananalisa aplikasi perancangan sistem informasi ini, maka dapat diperbolehkan beberapa kesimpulan untuk kelebihan , dengan adanya Sistem Informasi Digital Receptionist ini, sangat membantu dalam proses penerimaan tamu pada PT. Megasetia Agung Kimia. Perancangan Sistem Informasi Digital Receptionist sangat praktis bagi tamu, karyawan, Resepsionis, dan admin. Dengan adanya Digital Receptionist maka sistem semakin interaktif dan mampu meminimalisir tingkat penularan covid-19. Adapun kekurangan dalam aplikasi ini yaitu :Masih memerlukan fungsi resepsionis untuk melakukan transaksi untuk tamu yang tidak terjadwal

\section{REFERENCES}

[1] A. R. Setiawan, "Lembar Kegiatan Literasi Saintifik untuk Pembelajaran Jarak Jauh Topik Penyakit Coronavirus 2019 (COVID-19),” Edukatif J. Ilmu Pendidik., vol. 2, no. 1, pp. 28-37, 2020, doi: 10.31004/edukatif.v2i1.80.

[2] R. Nasruddin and I. Haq, "Pembatasan Sosial Berskala Besar (PSBB) dan Masyarakat Berpenghasilan Rendah," SALAM J. Sos. dan Budaya Syar-i, vol. 7, no. 7, 2020, doi: 10.15408/sjsbs.v7i7.15569.

[3] E. A. Sari, "Peran Pustakawan Ai (Artificial Intelligent) Sebagai Strategi Promosi Perpustakaan Perguruan Tinggi Di Era Revolusi 4.0," BIBLIOTIKA J. Kaji. Perpust. dan Inf., vol. 3, no. 1, pp. 64-73, 2019, doi: 
Journal of Computer System and Informatics (JoSYC)

Volume 3, No. 1, November 2021, Page 57-64

ISSN 2714-8912 (media online)

ISSN 2714-7150 (media cetak)

DOI 10.47065/josyc.v3i1.947

10.17977/um008v3i12019p064.

[4] A. Herliana and P. M. Rasyid, "Sistem Informasi Monitoring Pengembangan Software Pada Tahap," J. Inform., no. 1, pp. 41-50, 2016.

[5] Sopiyan Dalis, "Rancang Bangun Sistem Informasi Lembaga Penelitian Dan Pengabdian Masyarakat Berbasis Web," $J$. ECOTIPE, vol. 19, no. 1, pp. 1-8, 2017, doi: 10.33019/ecotipe.v4i1.14.

[6] E. Riana, "Implementasi Cloud Computing Technology dan Dampaknya Terhadap Kelangsungan Bisnis Perusahaan Dengan Menggunakan Metode Agile dan Studi Literatur," JURIKOM (Jurnal Ris. Komputer), vol. 7, no. 3, p. 439, 2020, doi: $10.30865 /$ jurikom.v7i3.2192.

[7] D. Prasetyo, N. Kusumo, S. Nita, U. P. Madiun, G. Adventure, and T. G. Mada, "Perancangan Game Android Adventure Gajah Mada dengan Metode Agile Development," Semin. Nas. Teknol. Inf. dan Komun., pp. 67-70, 2019, [Online]. Available: http://e-jurnal.lppmunsera.org/index.php/PROSISKO/article/view/116.

[8] T. M. Eka Wida Fridayanthie1, "RANCANG BANGUN SISTEM INFORMASI PERMINTAAN ATK BERBASIS INTRANET (STUDI KASUS: KEJAKSAAN NEGERI RANGKASBITUNG),” Appl. Microbiol. Biotechnol., vol. 85 , no. 1, pp. 126-137, 2016.

[9] E. Fridayanthie and T. Mahdiati, "Rancang Bangun Sistem Informasi Permintaan ATK Berbasis Intranet (Studi Kasus: Kejaksaan Negeri Rangkasbitung)," vol. IV, no. 2, pp. 1-10, 2016. 